\title{
SOVIET FOREIGN TRADE AGENCIES ABROAD: A NOTE $\dagger$
}

\author{
JoHN QUIGLEY*
}

Soviet trade agencies abroad play a crucial role in the conduct of foreign trade by the U.S.S.R. A variety of Soviet state agencies participate in this work. This article will attempt first to outline briefly their development, and then to examine their chief characteristics as they presently exist.

\section{Development of the Trade Agency}

The first permanent Soviet trade establishments abroad were organized by the People's Commissariat of Foreign Trade in the I920's. As Soviet trade with the West began to grow, the Commissariat set up trade delegations (torgovye predstavitel'stva) as an adjunct of the Soviet diplomatic mission in those Western nations that had recognized the Soviet state. These delegations enjoyed certain diplomatic privileges granted by treaty. In countries that had not yet recognized the Soviet state, the Commissariat formed corporations under local law, wholly owned by Soviet governmental agencies and officials. Important examples of such corporations, which were called trade agencies, are Arcos, Ltd. (London, founded in 1920) and Amtorg (New York, founded in 1924). ${ }^{1}$ These trade delegations and trade agencies sold nearly all Soviet export goods and purchased almost all imports.

Home-based foreign trade agencies-gostorgs (responsible for trade in a union republic) and joint-stock companies (responsible for trade in a particular line of products)-played a subordinate role at this period. While they were permitted to maintain agents in the trade delegations (and agencies), these agents were limited to advising the delegations and to participating in negotiations with foreign parties. But they were not permitted to negotiate independently, or to sign transactions in their own name. ${ }^{2}$ The only exception was the Gostorg of the Russian Republic, which was allowed to deal directly with foreigners for the export of certain raw materials, including flax and hemp. ${ }^{3}$

\footnotetext{
†For a fuller account of Soviet foreign trade institutions, see the author's forthcoming THE Sovier Foreign Trade Monopoly: Institutions and Laws (I973).

* Associate Professor, Ohio State University College of Law.

1 R. Karpova, L. Krasin: Sovetskil diplomat 83-86 (ig62); G. Kaliuzhinaia, Pravovye formy MONOPOLII VNESHNEI TORGOVLI SSSR V IKH ISTORICHESKOM RAZVITII 43 (I95I); B. VAGANOV, ORgANIZATSIIA I TEKHNIKA VNESHNEI TORGOVLI SSSR I DRUGIKH SOTSIALISTICHESKIRH STRAN 4 I (I963).

${ }^{2}$ S. Tokarev \& IU. Chel'Tsov, VNeshniaia torgovlia: pravovye osnovy vneshnego tovarooborota SSSR 66-68, 72 (1926); Chel'tsov, Organizatsiia importnoi torgovli, ENTSIRLOPEDIIA SOVETsKogo IMPORTA 50 (Iu. Goldshtein, ed. I929).

3 Tokarev \& CheL'Tsov, supta note 2, at 69; V. Pozdniakov, GosudarstevnNaia Monopolita vNeshnei TORGOVLI V SSSR 39 (rg69).
} 
With regard to exports, the gostorg (or joint-stock company) would apply to the Commissariat for an export license, which would be granted only if the proposed sale fell within the current annual export plan. The gostorg then purchased the goods through one of its local agencies, either by direct purchase or on a commission basis. ${ }^{4}$ In turn, it sold the goods through a trade delegation (or agency), which also operated on a commission basis, selling in its own name but on behalf of the gostorg. ${ }^{5}$ The trade delegation alone was responsible for the transaction with the foreign importer; no direct legal relations were created between the foreign importer and the gostorg. An alternate procedure was also used: where a foreign customer could not be found in advance, a trade delegation might purchase goods from a gostorg on a consignment basis, holding them in its warehouse abroad until it could locate a purchaser. ${ }^{6}$

Imports were handled in analogous fashion. The gostorg, having received an import license from the Commissariat, transmitted it to a trade delegation, which purchased the goods from a foreign supplier on a commission basis-in its own name but on behalf of the gostorg. Since the trade delegation purchased the goods in its own name, it alone entered into legal relations with the foreign supplier, no direct legal relations being formed between the foreign supplier and the gostorg. The gostorg might purchase import goods from the trade delegation in its own name for subsequent resale on the internal market or on a commission basis, upon request of a specific domestic economic organization. ${ }^{7}$ In the latter case, two separate commission relationships were created-one between the trade delegation and the gostorg, the other between the gostorg and the domestic economic organization.

This division of labor between the trade delegation abroad and the gostorg at home led to serious communication problems. A I928 decree advised the Commissariat of Foreign Trade "to take immediately measures to improve the ties of organizations procuring export goods with agencies selling them abroad, in order to ensure: (a) the possibility of quickly making the assortment, standards, etc., of export goods suitable for the needs of the foreign market; (b) timely notification to organizations procuring export goods about their sale, about difficulties arising in connection therewith, and about the reasons giving rise to such difficulties."

Contemporary authors criticized the trade delegations for failing to orient themselves properly in the complex markets of the capitalist world, ${ }^{0}$ for failing to penetrate new markets, ${ }^{10}$ for failing to fit Soviet goods to the requirements of

\footnotetext{
4 Torarev \& Chez'tsov, supra note 2, at 69.

'Id. at 65-66; R.S.F.S.R. Civil Code of r922, art. 275-a.

'Tokarev \& Chel'tsov, supra note 2, at 66.

${ }^{7}$ Chel'tsov, supra note 2 , at 50 .

${ }^{8}$ Sobranie zakonov SSSR (1928), No. 30, item 269, art. 8.

${ }^{\circ}$ Sushkov, Uroki eksportnoi kampanii $1928 / 29$ g., I929 EKonomicheskoe obozRenIE No. 12, at 136. ${ }^{10} \mathrm{Id}$.
} 
foreign markets, ${ }^{11}$ for failing to obtain adequate information about these markets, ${ }^{12}$ for failing to establish long-term relations with foreign companies, ${ }^{13}$ and for exporting certain goods at a time of year when prices were low instead of waiting for a seasonal price rise. ${ }^{14}$

With respect to imports, procedures were particularly cumbersome. They were especially inadequate to cope with the large volume of small orders with which the gostorgs continually bombarded the trade delegations. ${ }^{15}$ An individual enterprise, under the procedure then in effect, requested import goods through its superior agency, a trust, which forwarded the request to its superior agency, a combine or syndicate, which forwarded it to a gostorg, which forwarded it to a trade delegation (or agency). In many instances, neither the gostorg nor the trade delegation possessed expertise in the product involved. While this lengthy procedure might have been worth the trouble where large transactions were involved, it was too cumbersome for small sales. As a result, many state enterprises resorted to the illegal practice of ordering goods through foreign concessionaires. ${ }^{16}$

A major factor in the Commissariat's inability to cope with these tasks was an acute shortage of trained personnel. As Foreign Trade Commissar Leonid Krasin justly complained, tsarist Russia had not developed foreign trade expertise, since most trade had been handled by foreigners. ${ }^{17}$ While in domestic industry the Bolsheviks were able to draw on the know-how of specialists of the old regime, in foreign trade they were not so fortunate. ${ }^{18}$ Furthermore, in selecting personnel for posts abroad, the Commissariat was careful to ensure their political reliability. ${ }^{19}$

During the early 1930's, home-based foreign trade organizations were strengthened substantially. Out of the joint-stock companies of the r920's grew foreign trade combines (ob'edineniia) monopolizing the export or import trade, or both, in a particular line of goods. These Moscow-based combines gradually took operational functions away from the trade delegations. By I935 they had assumed the primary role in trading with foreign companies.

This transfer of the bulk of foreign trade operations to Moscow was advantageous to the Soviet Union for a variety of economic, political, and juridical reasons. From the economic point of view, it gave Soviet traders the natural advantage of operating on "home soil." Commissariat officials could more easily supervise the combines, and the combines could maintain closer relations with Soviet producers of export goods and users of import goods. Direct contact between the

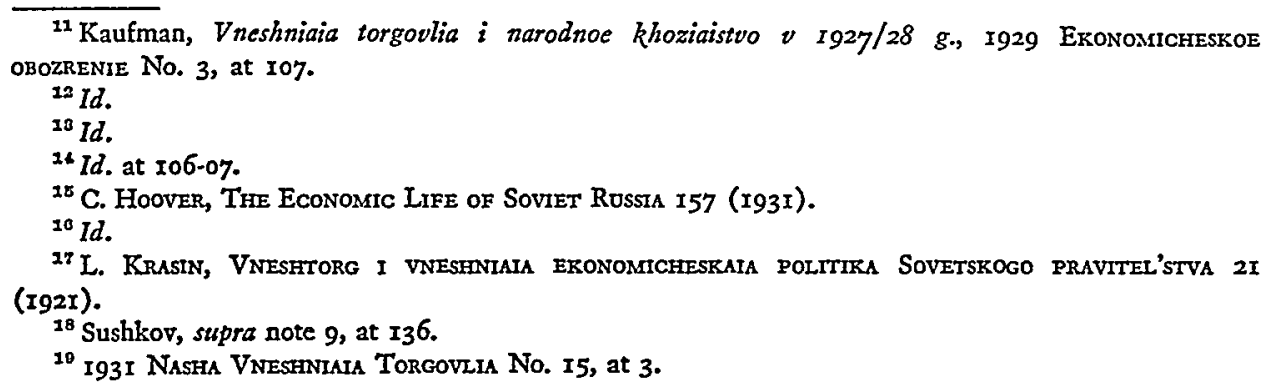


foreigner and the Soviet producer (or user) could more easily be arranged where appropriate, either through a visit by the foreigner to the Soviet enterprise or through participation of an enterprise representative in the negotiations. ${ }^{20}$ Reduction of staffs abroad meant that combine staffs could be bolstered with specialists familiar with capitalist markets. It also meant a considerable savings in foreign currency to maintain personnel abroad, and corresponding expenditures by foreign businessmen visiting Moscow. Operating in Moscow also served to improve the foreign businessman's confidence in the combine, reducing fears based on lack of familiarity with the Soviet Union. ${ }^{21}$ Finally, sale of exports from Moscow by F.O.B. and C.IF. contracts meant an end to consignment sales, which had involved extra transportation and storage costs. ${ }^{22}$

Transfer to Moscow also offered a number of advantages in the legal regulation of trade. Conclusion of contracts in Moscow made it more likely that foreigners would agree in the contracts to arbitrate in Moscow and to stipulate application of Soviet law. Where the parties did not choose a law to govern the contract, conclusion in Moscow made it more likely that a court or arbitration panel would select Soviet law as applicable. Furthermore, from a political standpoint, the transfer to Moscow provided a boost to Soviet international prestige at a time when the Soviet government was still trying to establish its respectability in the world community.

The movement of trade activity to Moscow was possible only because of substantial improvements in the U.S.S.R.'s economic position. Improved saleability of Soviet exports permitted elimination of consignment sales. ${ }^{23}$ With increased access to foreign credits as the Depression subsided, contracts were being concluded for longer periods of time, with a resultant decrease in the need for direct contact with the foreign party. ${ }^{24}$ Most importantly, as a result of production increases, the Soviet Union was, by 1935, much less reliant on foreign goods than it had been during the early years of the First Five-Year Plan. ${ }^{25}$ Imports, which reached a high of 866 million rubles in I93I, had by 1935 been cut to a level of 189 million rubles. ${ }^{20}$ This drastic reduction in import requirements led to a significant improvement in the U.S.S.R.'s balance of payments position, and allowed the Soviet government to require Western merchants to make the pilgrimage to Moscow without fear that domestic production plans would be seriously jeopardized if certain of them balked at the idea. "Now the sword of Damocles does not hang over us, to sell come what may," said the Soviet Trade Delegate to Sweden. "We can hold out on prices and dictate our terms to the world market."27

\footnotetext{
${ }^{20}$ r936 Vneshniaia Torgovlia No. 14 , at 7.

${ }^{21}$ Id. at 13 .

22 Vaganov, supra note $\mathrm{I}$, at 32; 1936 VNeshniata Torgovila No. 7, at 13-I4.

${ }^{28}$ M. Zhirmunskit, Organizatsiu I tekhikika sovetskogo eksporta r88 (I938).

${ }^{24}$ Id.; A. Baykov, Soviet Foreign Trade 5 (1946).

${ }^{25}$ ZhIRMUNSKII, supra note 23 , at 187 .

${ }^{26}$ Ministry of Foreign Trade of the U.S.S.R., VNeshniaja Torgovla SSSR: Statisticheskit SBORNIx, 19I8-1966 (1967).

${ }^{27}$ Nepomniashchii, 1936 Vneshniaia Torgovlia No. I4, at 21.
} 
From the foreign businessman's point of view, the transfer of trade operations to Moscow was a mixed blessing. Amtorg explained in a letter to its U.S. suppliers that transactions would be carried out directly with a combine in Moscow and that Amtorg's only function would be to inspect goods before shipment to the U.S.S.R. ${ }^{28}$ The need to travel to Moscow worked a hardship, especially on smaller companies, but at the same time it expedited negotiations and facilitated contact with Soviet production enterprises. ${ }^{29}$ The new system of dealing directly with the combine eliminated the possibility that the trade delegation might cancel an order provisionally given by a combine. ${ }^{30}$

\section{II}

\section{Present Characteristics}

Since 1935, Soviet trade delegations abroad have not carried on trade directly with foreigners on any substantial scale. They do, however, exercise important organizational and regulatory functions. They supervise those combines trading in the country where the delegation is located, and, in particular, see that the combines observe Soviet foreign trade legislation. When a combine concludes a foreign trade contract in Moscow, it must send a copy to the trade delegation in the relevant country. If a combine sends a representative abroad to inspect goods being purchased, that representative is, during his stay, administratively subordinate to the trade delegation, though in his inspection activities he remains subject to the orders of the combine. ${ }^{31}$ Trade delegations also issue permits to import goods into the U.S.S.R., documents on the origin of goods, and permits to transship goods through the U.S.S.R. In addition, they study the economy of the receiving state and inform local companies about opportunities for trade with the U.S.S.R. ${ }^{32}$

The trade delegations retain the legal power to conclude actual trade transactions, though they do not frequently exercise this power. They almost never contract in their own name, though they occasionally contract as agent for a combine or guarantee a combine's obligation. ${ }^{33}$ When trade delegation personnel sign as agent for a combine, the combine alone becomes a party to the contract, and neither the trade delegation nor the Soviet state is liable. When, however, they sign as primary contractor or guarantor, the trade delegation and the state are liable, since the trade delegation, unlike the combine, is not an independent legal entity. ${ }^{34}$

Soviet legislation regulates quite carefully the formalities of contracts concluded in the name of a trade delegation. The contract must be in writing. If the amount

\footnotetext{
${ }^{28}$ N.Y. Times, Oct. 20 , 1936, at 45 , col. 3 .

${ }^{20}$ N.Y. Times, Aug. II, I935, at 26, col. 6.

${ }^{30}$ The Times (London), Aug. 8, 1935, at II, col. 3 .

31 P. Cherviarov, Organizatsita I tekhnika vNeshnei torgovli SSSR 48 (Ig62).

${ }^{32} \mathrm{~V}$. Chkmikvadze, 4 Kurs Mezhdunarodnogo prava 122 (1968); Statute on Trade Delegations and Trade Agencies Abroad, Sobranie zakonov SSSR (I933), No. 59, item 354, art. 3 .

${ }^{33}$ Cherviazov, supra note 31 , at 48 .

st Id.
} 
in question does not exceed 40,000 rubles, the trade delegate (head of the delegation) may sign at his own discretion; if over 40,000 rubles, the trade delegate must obtain permission from the Foreign Trade Minister (or a deputy minister) in Moscow. ${ }^{35}$ Alternately, a trade delegation contract may be signed by two persons, one of whom must be the trade delegate, deputy trade delegate, or (with the trade delegate's authorization) the head of a department of the trade delegation. The other may be any staff member named in a list of persons authorized to sign contracts. This list is communicated to the government of the receiving country and is printed in an appropriate publication of that country. ${ }^{36}$

While Soviet doctrine holds the state liable on the obligations of a trade delegation, it also holds that a trade delegation, as an arm of the state, may not be sued in a foreign court because of the doctrine of sovereign immunity. Since, however, many Western courts have refused to grant such immunity, the Soviet government regularly includes in trade treaties a provision subjecting the trade delegation to the jurisdiction of local courts for commercial obligations undertaken in that country, but relieving it of liability on other civil-legal claims. ${ }^{37}$ Thus, the practical significance of the Soviet claim of immunity for the trade delegation is not great, both because of the customary treaty waiver and because of the infrequency with which trade delegations contract in their own name. Also, as part of the Soviet embassy establishment of the receiving state, a trade delegation enjoys, by treaty, certain diplomatic privileges: immunity of its buildings, the right to use cipher, personal diplomatic immunity for the trade delegate and several other top officials, immunity from income tax for all trade delegation employees, and exemption from enrollment in local trade registers. ${ }^{38}$

Since it may be involved in matters affecting Soviet foreign policy, a trade delegation is subject, in certain respects, to the Ministry of Foreign Affairs of the U.S.S.R. The trade delegate and deputy delegates are appointed by the Council of Ministers of the U.S.S.R. on nomination by the Foreign Trade Minister, who must, however, obtain consent to the nomination from the Minister of Foreign Affairs. ${ }^{39}$ The Foreign Trade Ministry must also consult with the Ministry of Foreign Affairs in establishing the size of a trade delegation and in appointing

\footnotetext{
${ }^{85}$ Decree of the Central Executive Committee and Council of People's Commissars on the Procedure for Signing Foreign Trade Transactions, Dec. 26, 1935, Sobranie zakonov SSSR (1936), No. I, item 3.

${ }^{86}$ Decree of the Central Executive Committee and Council of People's Commissars on the Procedure for Signing Transactions and Issuing Authorizations for Performance of Foreign Trade Opcrations, Oct. I3, I930, Sobranie zakonov SSSR (1930), No. 56, item 583. See also L. Lunts, Mezhdunarodnoe Chastnoe Pravo-Osobennata Chast' 5 58-59 (1963).

${ }^{87}$ Fensterwald, Sovereign Immunity and Soviet State Trading, 63 Harv. L. Rev. 634-39 (1950). See also D. Genkin, Pravovoe regtulrovanie VNeshnei torgovl SSSR 29 (196I); an example of such a provision may be found in article 4 of the Appendix to the 1958 Trade and Navigation Treaty between the U.S.S.R and the Federal Republic of Germany, in Ministry of ForeIGN AFfairs of the U.S.S.R., 21 SBORNIK DEISTVUIUSHCHIKH DOGOVOROV, SOGLASHENII I KONVENTSII, ZAKLIUCHENNYKII SSSR S INOSTRANNYMI GOSUDARSTVAMI 255-56 (1967).

${ }^{38}$ See, e.g., art. 2 of the I958 U.S.S.R.-German trade treaty, supra note 37.

${ }^{8 \theta}$ Statute on Trade Delegations and Trade Agencies of the U.S.S.R. Abroad, supra note 32, art. 7.
} 
personnel below the rank of deputy trade delegate. ${ }^{40}$ The head of the diplomatic delegation in the particular country has the right to suspend any trade delegation operation that he considers politically inappropriate. ${ }^{41}$

Each trade delegation is directly subordinate to Moscow. During the I920's and early I930's, when the trade delegations conducted much trade on their own, competition developed among them, and as a result the Commissariat appointed the trade delegation in Berlin to coordinate the activities of all trade delegations in Europe. ${ }^{42}$ However, the need for such coordination disappeared when the combines assumed primary responsibility for trade in 1935 .

A trade delegation may, with permission of the Ministries of Foreign Trade and Foreign Affairs, open a branch office in another city of the country to which it is accredited. ${ }^{43}$ The right of the Soviet Union to open such offices is often stipulated in the trade agreement with the particular country. ${ }^{44}$ The heads of such offices are called plenipotentiaries of the given trade delegation, but they are appointed by, and are directly subordinate to, the Foreign Trade Minister in Moscow, not to the trade delegate. ${ }^{45}$

The system of trade delegations has been extremely useful to the Soviet foreign trade system. During the early years they conducted trade. While at present their functions are much more limited, they still coordinate the activities of combines and assist them with their knowledge of local conditions. As the combines become more and more knowledgeable through long experience, however, the importance of these trade delegation services will diminish.

Commercial counsellors (or attachés) in Soviet embassies perform the functions of a trade delegation in those countries where the U.S.S.R. has no trade delegation. ${ }^{\mathbf{1 6}}$ These officers and their small staffs may be replaced by a full trade delegation as trade with the given country increases. ${ }^{\mathbf{4 7}}$ Soviet consulates perform only limited commercial function's, studying the local economy and keeping Moscow informed of performance under trade treaties. ${ }^{48}$

The Soviet Union has also established commercial corporations in foreign coun-

${ }^{10}$ Id., art. 8; Chkhikvadze, supra note 32, at 123 .

¿1. Blishchenko \& A. Piradov, in F. Kozhevnikov, Kurs mezandunsrodnogo prava 38 I (1966).

${ }^{43}$ Hoover, supra note I5, at I60; I93I Nasha VNeshniaia Torgovlia No. 3, at 20.

${ }^{43}$ Statute on Trade Delegations and Trade Agencies of the U.S.S.R. Abroad, supra note 32, art. II; Cherviatzov, stupra note $3 \mathrm{r}$, at 48 .

"See, e.g., the 1947 trade agreement between the U.S.S.R. and Finland, the Appendix to which (article 2) permits a branch office in Turku. Ministry of Foreign Affairs, supra note 37, at 35r.

${ }^{6}$ Statute on Trade Delegations and Trade Agencies of the U.S.S.R. Abroad, supra note 32, art. II; Cherviakov, sitpra note $3 \mathrm{I}$, at 48 ; Genkin, supra note 37 , at 27 .

${ }^{10}$ VAGANOv, supra note $I$, at 30-3I; Genkin, supra note 37, at 27.

${ }^{17}$ Vaganov, supra note $I$, at 30-3I. The United Arab Republic, Pakistan, and Indonesia are cited as countries where commercial counsellors were subsequently replaced by trade delegations.

${ }^{8 B}$ The 1926 Consular Statute of the U.S.S.R. provides for use of consulates to conduct trade when necessary. Sobranie zAKonov SSSR (1926), No. Io, item 78, art. 20, translated by Harold J. Berman and William E. Butler in 3 Soviet Statutes and Decisions 59-60, Nos. 2-3 (Winter-Spring r967). See also art. 28 of the same Statute. Iu. Il'in, Konsul'stva $i$ vneshniaia torgovlia, Sovetsmoe gosudarstvo I pRavo, No. 8 (r966) at 134-35, suggests that consulates should be utilized more in foreign trade, especially in those countries where there is no trade delegation. 
tries under the local corporation law, the stock being owned by Soviet government agencies either in toto, or jointly with local business interests. This device is used either for general trade (in countries having no trade delegation) or for trade in a particular product. The first such company was Arcos, Ltd., formed in London in 1920 to handle general Soviet-British trade. ${ }^{40}$ Arcos was subsequently absorbed by the Soviet trade delegation in London.

Another such foreign company is the Amtorg Trading Corporation in New York City (the acronym Amtorg means "American trade"), organized under the corporation law of the state of New York. While the U.S.S.R. maintains a commercial counsellor's office in its Washington, D.C. embassy, it nonetheless utilizes Amtorg for most of its operations and much of its commercial advisory work in the United States. Amtorg was established in $x 924$ and continued operations after establishment of diplomatic relations with the United States in I933, since the U.S. government refused to admit a Soviet trade delegation with diplomatic status.

A controlling share of Amtorg's stock is held by the Foreign Trade Bank in Moscow, while the remaining shares are held by Centrosoiuz (a Soviet consumer cooperative) and by two officers of the corporation, both Soviet citizens. Amtorg enjoys no diplomatic privileges. It is subject to municipal, state, and federal regulation, and to suit in court just like any other New York corporation. When, in 1949, Amtorg declined to register with the U.S. Justice Department under the Foreign Agents Registration Act of 1938 , six of its officers were arrested, though charges were later dropped following Amtorg's registration. ${ }^{50}$ While its principal function is advisory-to put American companies in touch with appropriate Soviet combines and to counsel them on trade with the U.S.S.R.-it frequently concludes contracts as agent for a combine (though never in its own name).

In addition to operating wholly-owned companies like Amtorg for general trade, Soviet agencies also participate in joint Soviet-foreign companies for specialized trading. The Russian Wood Agency, owned jointly by the combine Exportles (timber export) and British brokerage firms, has been marketing Soviet timber products in Britain as a British corporation since $1923 .{ }^{\text {b1 }}$ By operating its own agency rather than selling through British brokers, the Soviet government is able to maintain better control over the terms on which Soviet timber is sold, and to save brokerage fees. ${ }^{52}$

Another joint undertaking is the Helsinki-based Soviet-Finnish corporation Konela (established in 1947), which purchases Soviet motor vehicles-chiefly automobiles-from the appropriate combines for sale in Finland through its own retail outlets and through independent Finnish dealerships. Konela purchases parts from

\footnotetext{
${ }^{40}$ On the creation of Arcos, Ltd., see note I supra.

${ }^{80}$ For reports of these proceedings, see N.Y. Times, Oct. 22, 1949, at r, col. 4; Oct. 25, 1949, at 12, col. 2; Oct. 27, I949, at I, col. 7; Oct. 28, I949, at I8, col. 4; Nov. 24, 1949, at 53, col. I; Dec. 9, 1949, at 13, col. 5 .

${ }^{52}$ VAGANOV, supra note $\mathrm{I}$, at $4 \mathrm{I}$.

${ }^{52}$ S. Liberman, Building Lenin's Russia 139-40 (1945).
} 
the spare parts combine Zapchastexport and provides repair services at its retail sales outlets. ${ }^{53}$ The mixed-company device has undoubtedly facilitated adaptation to the Finnish market in advertising, sales, and service of Soviet automobiles, since it has permitted extensive utilization of local expertise in these matters. ${ }^{54}$ The U.S.S.R. also operates a mixed Soviet-Swedish corporation, Matreco Bil, on a basis similiar to Konela, as well as mixed corporations in Norway (Konela-Norge-Bell), France (Aktif-Auto), and Belgium (Scaldia-Volga). ${ }^{55}$

The device of the jointly-owned corporation has not been used solely to sell and service Soviet products. It has been used as well, in recent years, to participate in joint international ventures, particularly in the export and import of oil. The Nafta Corporation, formed in Antwerp in 1967 (sixty per cent Soviet-owned and forty per cent Belgian-owned) distributes Soviet oil products in Belgium. ${ }^{56}$

The operations undertaken by Russian Wood, Konela, and Nafta are too large in scope to be run out of an embassy or consulate, or even out of a trade delegation responsible for trade in many products. Therefore, as Soviet trade increases in volume, additional mixed companies will likely be formed.

\section{CONCLUSION}

This paper has attempted to present a description of the structure and operation of the agencies through which the Soviet Union effects its foreign trade. As might be expected, the development of these agencies has been evolutionary in nature, and adjustments in form and practice have been responsive to changes in the nature of Soviet trading. We can, of course, anticipate the further development of trading relationships as well as a continuing search for more efficient organizational structures. Hence, the process of refinement of the Soviet trading apparatus has by no means been finalized.

\footnotetext{
${ }^{53}$ In general, the Foreign Trade Ministry has been slow to develop repair service for the machinery it sells abroad. Shereshevskii, Osnovnye cherty $i$ zadachi organizatsii vneshnei torgovli SSSR posle vtoroi mirovoi voiny, in INSTITUTE OF INTERNATIONAL RELATIONs, VopRosY VNESHNEI TORGOVLI II (1960).

"See Engibarov, Director of Konela, "Konela"-Sovetsko-finskoe aktsionernoe obshchestvo, ig66 VNeshiniata Torgoveis No. 6, at 38-42.

${ }^{65}$ See Darchiev, Tekhnicheskoe obsluzhivanie sovetskikh avtomobilei v Shvetsii, x968 VNESHNIAIA TORGOVLIA No. 5, at 32; Myshkov, Zapasnye chasti $k$ avtomobilizam i sel'sko-khoziaistvennoi tekhnike, r969 VNeshintata Torgovita No. 5, at 42. Scaldia-Volga assembles automobiles in addition to selling and servicing them. Goldman, The East Reaches for Markets, 47 ForeIgN AfFaIRs 73I (I969).

${ }^{50}$ Goldman, stipra note 55, at 731-32. S. Pisar, Coexistence and Commerce: Guidelines for TransACTIONS BETWEEN EAST AND WEST 153 (1970). For additional examples of joint undertakings, see Goldman at 730-33, and PISAR at 153 .
} 